\title{
State and the Protection of the Minority Rights in Indonesia: The Case of the Ahmadi Group
}

\author{
Dani Muhtada \\ Department of Constitutional and Administrative Law \\ Faculty of Law, Universitas Negeri Semarang (UNNES), Indonesia \\ Email:dmuhtada@mail.unnes.ac.id
}

\section{INTRODUCTION}

The tragedy of Cikeusik has been the worst religious conflict involving the Ahmadi people in Indonesia. In February 6, 2011, a group of people attacked an Ahmadi neighborhood in Cikeusik, Banten. Three Ahmadi people were killed, some people were injured, two cars were burnt, and a house was severely damaged [11]. This was unfortunate since another attack to Ahmadi people just happened three months ago in Gegerung, Lombok. A number of houses belonged to the Ahmadi people were destroyed, one of which was burnt [16]. A month before this incident, another incident happened in Cisalada, Bogor. In this incident, a mosque and a number of houses were also burnt by the attackers [7].

Legally speaking, the violence against the Ahmadi people in this country is never acceptable. As far as state ideology is concerned, Indonesia has been a state with an inclusive nationalist ideology [6]. In other words, citizens from any religious beliefs would be treated similarly without any discrimination. Pancasila, which is the ideology of the state, promotes a freedom of religion. The Indonesian constitution (i.e., UUD 1945) articulates very clearly such a freedom of religion. It grants a freedom for Indonesian citizens to practice their religious beliefs.

Unfortunately, as reported by Setara Institute [14], there is an increase trend of the violence against the Ahmadi group in the last ten years. In 2009, for example, there were at least 33 violence cases experienced by the Ahmadi people recorded by Setara Institue. The number increased to 50 cases in 2010. Such an increase trend of the violence is surprising for two main reasons. First, the Ahmadi people have been living in the country since the 1920s [2], [8], twenty years before the independence of Indonesia, and they have been enjoying a relatively peaceful life. There were some small tensions between the Ahmadi people members and other Muslim organizations such as Muhammadiyah, Nahdlatul Ulama, and Persis. Yet, there was no significant physical clash between them recorded until the reformation era. Most of these tensions were resulted from the different interpretation on the prophecy after the prophecy of Muhammad. To deal with these differences, Ahmadiyyah tended to invite open debates and to publish books clarifying its religious beliefs and practices.

Second, this increase trend of the violence happened under the democratic regime, in which democratic values such as a freedom of religion should have a place. More surprisingly, not only the government has failed to protect the rights of the Ahmadi people to practice their religious beliefs, some components in the government have demonstrated discrimination against this particular religious group. The Minister of Religious Affairs, for example, made a controversial statement regarding the disbandment of Ahmadiyah. Several governors (e.g., East Java, West Java, South Sulawesi) and regents (e.g., West Lombok, Kuningan, Garut) have banned the Ahmadi group's activities in their regions [10], [1] the Ahmadi people in her province. She even urged the Ahmadi people, the victims of the violence, to come return to the "right" ways of Islam [9]. These phenomena imply that some governments have moved from being neutral in dealing with religious conflicts to acting discriminatively against a particular group of religion.

This paper focus to answer the question about why the central government and some governments at provincial and municipal levels produce policies that discriminate against the Ahmadi people, despite the fact that freedom of religion is guaranteed by the constitution and the fact that Indonesia is currently undergoing the process of democratization after a long period of authoritarianism. Two possible answers are evaluated in this paper. First, the government did so to reach certain political agenda (rational choice). Second, the government received a strong political pressure to do so from particular interest groups (a weakening government). To begin with, the paper provides a historical background of Ahmadiyah in Indonesia. Then, it discusses the two hypotheses and analyzes arguments underpinning the hypotheses. Conclusion is presented afterwards.

\section{UNDERSTANDING THE CONTEXT}

Ahmadiyah came to Indonesia in the 1920s, when a number of Ahmadi preachers from South Asia visited Aceh and Yogyakarta [2]; [8]. Ahmadiyah itself was founded in Punjab, India, in 1888 by Mirza Ghulam Ahmad [8]. This means that Ahmadiyah came to Indonesia less than 20 years after it was established its "home" country. The history of Ahmadiyah then shows that this organization split into two factions: the Lahore and the Qadiani. One of the fundamental differences between these two factions lies on the belief of the prophecy of Mirza Ghulam Ahmad. The Lahore considers Mirza 
Ghulam Ahmad as a "reformer", not as a prophet like the Prophet Muhammad. On the contrary, the Qadyani believes that Mirza Ghulam Ahmad as a prophet and a promised messiah for human beings [4], [3]. Such a belief of the Ghulam Ahmad prophecy is unacceptable to the orthodox Islamic groups, including Muhammadiyah and Nahdlatul Ulama.

In Indonesia, the Lahore branch is known as Gerakan Ahmadiyah Indonesia (GAI), while the Qadiani branch is known as Jemaah Ahmadiyah Indonesia (JAI). Unfortunately, not all of the orthodox Muslims in Indonesia are aware of the difference between the Lahore and the Qadyani. What the orthodox Muslims generally know is that the Ahmadi group is a sect of "Islam" that believes in the prophecy of Mirza Ghhulam Ahmad, regardless of the distinction between the Lahore and the Qadiani factions. This concept of prophecy becomes a central dispute and a source of conflict between the Ahmadi and the orthodox Muslims. It is worth mentioning that, in the early development of Ahmadiyah, Muhammadiyah was very welcome the Ahmadi preachers (Zulkarnaen; 2005). They saw no fundamental difference between Ahmadiyah and Muhammadiyah. This could happen because their first encounter with Ahmaidyah is with the Ahmadi preachers from the Lahore faction. However, soon after the movement of Qadiani faction got more influences on the Muslim society in Indonesia, the Muhammadiyah leaders become more aware of the Ahmadi's principles and decided to "stay away" from this organization.

Tensions then started to emerge, not only between Ahmadiyah and Muhamadiyah, but also between the Ahmadi and other Islamic groups (e.g., NU, Persis, PSSI, Perti, etc.). In the $8^{\text {th }}$ Islamic Congress in Pekalongan (1927), for example, the delegations from Muhammadiyah and NU agreed to reject the Ahmadiyah's version of the translation of the Quran [8]. These organizations also issued a decree canceling the memberships of the Ahmadi people within Muhammadiyah and NU. Since then, a number of efforts have been made by the groups of orthodox Mulisms to hinder the development of Ahmadiyah in Indonesia. In 1933, a national debate was held in Jakarta to determine whether Ahmadiyah is part of Islam or not. The debater was A. Hassan, a chairman of Persis, and Abubakar Ayyub, a national figure of the Qadiani [17]. In 1934, the Legal Council of Muhammadiyah (Majlis Tarjih) issued a fatwa stating that those who believe in the prophecy after the prophecy of Muhammad are considered as the "unbeliever" or kafir [4]. In 1965, the Ulema of East Sumatera issued a fatwa against the Qadiani [3]. In 1980, the Council of Indonesian Ulema (Majlis Ulama Indonesia) issued a fatwa stating that the Ahmadi is a group of non-Muslims [12]. A table 1 below (adopted from [3]) indicates a list of fatwa issued by the groups of orthodox Muslims to hinder the spread of Ahmadiyah among Indonesian Muslims after 1980.

Table 1 - Fatwa against Ahmadiyah in Indonesia

\begin{tabular}{|l|l|}
\hline Year & Fatwa \\
\hline 2007 & $\begin{array}{l}\text { The MUI fatwa on guidelines to evaluate whether a } \\
\text { religious teaching is considered deviant }\end{array}$ \\
\hline 2005 & The MUI fatwa number 11/Munas \\
\hline
\end{tabular}

\begin{tabular}{|c|c|}
\hline & VII/MUI/15/2005 on Ahmadiyah \\
\hline 1995 & $\begin{array}{l}\text { The Shuriyah (Council of Ulema) of Nahdlatul } \\
\text { Ulema's fatwa on Ahmadiyah }\end{array}$ \\
\hline 1994 & $\begin{array}{l}\text { The Forum Ukhuwah Islamiyah Indonesia (FUUI) } \\
\text { fatwa on the Qadiani }\end{array}$ \\
\hline 1994 & $\begin{array}{l}\text { The Riau Ulema's fatwa (Fatwa MUI Riau) on the } \\
\text { Qadiani }\end{array}$ \\
\hline 1984 & $\begin{array}{l}\text { The Ulema Council of Aceh's fatwa on the } \\
\text { Qadiani }\end{array}$ \\
\hline 1980 & $\begin{array}{l}\text { The North Sumatera Ulema's fatwa (Fatwa MUI } \\
\text { Sumut) on Ahmadiyah }\end{array}$ \\
\hline
\end{tabular}

It is important to note that although many efforts have been made by the Islamic groups to block the spread of Ahmadiyah, and despite some tensions between these dominant Islamic groups and the Ahmadi, the government still maintained its neutral position in dealing with religious conflicts. Indeed, during the authoritarian regime (i.e, the Suharto era), there were a few policy issued by local government that discriminated against the Ahmadi people. Yet, the number of the discriminating policy against this group has increased significantly since the era of reformation (the post-Suharto's democratic regimes), and these policies were issued by several government at all levels (i.e., municipal, provincial, and national). The table 2 below (adapted from [2] and [3] illustrates those discriminative policies issued between 2001 and 2008 . This data does not include a number of other discriminative policies issued after 2009 such as the prohibition of the Ahmadi's activities by the governors of East Java, West Java, and South Sulawesi.

Table 2 - The Government Policies against Ahmadiyah

\begin{tabular}{|l|l|l|}
\hline Government Policy & Region & Year \\
\hline $\begin{array}{l}\text { The decree of the South } \\
\text { 5umatera governor No. }\end{array}$ & $\begin{array}{l}\text { South Sumatera } \\
\text { (Provincial) }\end{array}$ & 2008 \\
$\begin{array}{l}\text { KESBANGPOL \& } \\
\text { LINMAS/2008 on banning the } \\
\text { Ahmadiyah activities }\end{array}$ & \\
\hline $\begin{array}{l}\text { Joint decision between the } \\
\text { Ministry of Religious Affairs, } \\
\text { the Minister of Home affairs, } \\
\text { and the Attorney General (8 \& } \\
\text { 9/2008) that order Ahmadiyah } \\
\text { to stop spreading teachings that } \\
\text { violate "the Islamic principles" }\end{array}$ & $\begin{array}{l}\text { Indonesia } \\
\text { (National) }\end{array}$ & 2008 \\
\hline $\begin{array}{l}\text { The decree issued by the mayor } \\
\text { of Cimahi to ban Ahmadiyah }\end{array}$ & $\begin{array}{l}\text { Cimahi, West Java } \\
\text { (Municipal) }\end{array}$ & 2008 \\
\hline $\begin{array}{l}\text { The Bakor Pakem's } \\
\text { recommendation to ban }\end{array}$ & $\begin{array}{l}\text { Indonesia } \\
\text { (National) }\end{array}$ & 2008 \\
$\begin{array}{l}\text { Ahmadiyah activities in } \\
\text { Indonesia }\end{array}$ & & \\
\hline $\begin{array}{l}\text { The Tasikmalaya Regent's } \\
\text { decree No. 450/174/KBL/2007 } \\
\text { on the ban of Ahmadiyah }\end{array}$ & $\begin{array}{l}\text { Tasikmalaya } \\
\text { (Municipal), West }\end{array}$ & 2007 \\
\hline $\begin{array}{l}\text { The decree issued by the } \\
\text { government of Garut to ban the } \\
\text { operation of JAI }\end{array}$ & $\begin{array}{l}\text { Garut (Municipal), } \\
\text { East Java }\end{array}$ & 2005 \\
\hline $\begin{array}{l}\text { The decree issued by the } \\
\text { government of Bogor to close } \\
\text { the Ahmadiyah's Mubarak } \\
\text { campus }\end{array}$ & $\begin{array}{l}\text { Bogor } \\
\text { (Municipal), West }\end{array}$ & Java \\
\hline
\end{tabular}




\begin{tabular}{|l|l|l|}
\hline $\begin{array}{l}\text { The decree issued by the regent } \\
\text { of Sintang to ban the activities } \\
\text { of JAI }\end{array}$ & $\begin{array}{l}\text { Sintang } \\
\text { (Municipal), West } \\
\text { Kalimantan }\end{array}$ & 2005 \\
\hline $\begin{array}{l}\text { The decree issued by the regent } \\
\text { of Kuningan to ban the } \\
\text { operation of JAI (SKB 1 \& SKB } \\
2 \text { ) }\end{array}$ & $\begin{array}{l}\text { Kuningan } \\
\text { (Municipal), West } \\
\text { Java }\end{array}$ & $\begin{array}{l}2002 \\
\text { and } \\
2004\end{array}$ \\
\hline $\begin{array}{l}\text { The decree issued by the regent } \\
\text { of East Lombok to ban } \\
\text { Ahmadiyah }\end{array}$ & $\begin{array}{l}\text { East Lombok } \\
\text { (Municipal), West } \\
\text { Nusa Tenggara }\end{array}$ & 2002 \\
\hline $\begin{array}{l}\text { The decree issued by the regent } \\
\text { of West Lombok to ban } \\
\text { Ahmadiyah }\end{array}$ & $\begin{array}{l}\text { West Lombok } \\
\text { (Municipal), West } \\
\text { Nusa Tenggara }\end{array}$ & 2001 \\
\hline
\end{tabular}

Source: Abidin (2007) and Crouch (2009)

\section{BEHIND THE POLICY}

Thus, why did these municipal, provincial, and central governments issue policies that discriminate against the Ahmadi group, despite the fact that freedom of religion is guaranteed by the constitution and the fact that Indonesia is currently undergoing the process of democratization? Two answers are possible. First, the government did so to reach particular political agenda (rational choice argument). This could be either the government (i.e., the incumbent) wants to get reelected in the next election or the government wants to distract people's attention from internal governance problems (e.g., corruption, mismanagement). The first reason (i.e., to get reelected in the upcoming election) is possible because some of those governors and regents might plan to run for the second term. For example, the East Java (i.e., Soekarwo) and the West Java Governors (Ahmad Heryawan) might be planning to run for the second term because they are still in their first terms. The second reason (i.e., to distract people's attention) is also possible. Teten Masduki, a national figure that has a strong reputation as an anticorruption activist, believes that the issue of Ahmadiyah was design to distract people's attention from legal problems currently faced by the government [13]. Fuad Bawazier, one of the chairmen of the Hanura Party, also believes that the Ahmadi conflict is used to distract keep the public eyes away from the current governance challenges [15].

However, two political facts can make this rational choice argument rather unconvincing. First, some of the incumbents issuing the Ahmadi policies have been in their second terms. The mayor of Cimahi (i.e., Itoc Tochija), for example, has been in his second term when he issued the city regulation to ban Ahmadiyah. Hence, the argument saying that the incumbents want to get reelected for the second term might not be entirely true. Second, saying that the policy was issued to distract people's attention violates the fact that many municipal and provincial governments do not issue the Ahmadiyah policy. In fact, these governments might face the same governance problems as those who issue the Ahmadiyah policy. If the policy was truly issued to distract the public attention, then the other governments should also be issuing a similar Ahmadiyah policy for their regions.
Again, this argument might be true but, definitely, it is not entirely true for all contexts of Indonesian governments.

The second possible answer is more "promising" than the one. It is said that those governments generate the discriminative policy against the Ahmadi group mostly because of a strong pressure from interest groups. Why did these groups successfully "force" the governments to issue the policies? Why do they fail to do same thing during the Suharto government? Two arguments can explain this. First, the current democratic governments (at municipal, provincial, national levels) are relatively weaker than the previous governments under the authoritarian regime. During the Suharto regime, all levels of government were controlled under the centralized power of the central government. It is also undeniable that Jakarta often used "military hands" to maintain national and local stabilities. This situation is absent during the current democratic regime. Each head of provincial or municipal governments is elected directly by the people and they enjoy a certain degree of autonomy to govern their regions. In addition, since the ruling party varies by region, a governor or a mayor might have a double accountability. They might have to be accountable to the central government, and the same time, also have to be accountable to their own party. This makes the current government even weaker because they have to "negotiate" power with multiple political actors. Second, the reformation era has significantly contributed to strengthening the Islamic fundamentalist movements in Indonesia. Factors such as a greater political participation, a freedom of association, and a greater freedom to articulate ideas and aspirations have strengthened a bargaining position of fundamentalist groups in the country. This situation could not be found during the New Order regime. Suharto was successfully "control" these groups in the name of national stability. This is why these groups were never able to impose their aspirations (e.g., banning Ahmadiyah, the notion of Islamic state, etc.) during the Suharto government. The era of reformation has enabled them to do so.

\section{CONCLUSION}

In conclusion, this paper argues that institution matters. The weakening state has significantly contributed to the establishment of discriminative policies against the Ahmadi people issued by national and several provincial and municipal governments. The social and political condition resulted from the euphoria of democratization has enabled Islamic fundamentalist groups to consolidate among themselves and to strengthen their bargaining position vis a vis the government. These two factors, a weakening state and a stronger Islamic fundamentalism, have made the Ahmadi people the victim of the era of reformation.

\section{REFERENCES}

[1] Aisyah, A. Gubernur Sulsel larang Ahmadiyah. Retrieved from www.okezone.com, 2011

[2] Abidin, Z. Syarif Ahmad Saitama Lubis: Dari Ahmadiyah untuk Bangsa, Yogyakarta: Logung Pustaka, 2007. 
[3] Crouch, M. Islam, militant Islam and Ahmadiyah: Origins and implications. Islam, Syari'ah and Governance Background Paper Series. Centre for Islamic Law and Society, Melbourne Law School, The University of Melbourne. Retrieved from www.lindseyfederation.law.unimelb.edu.au, 2009.

[4] Djamaluddin, M. A. Ahmadiyah Menodai Islam: Kumpulan dan Fakta, Jakarta: Lembaga Penelitian dan Pengkajian Islam (LPPI)

[5] Firdaus, F. (2011). Inilah alasan Gubernur Jabar larang Ahmadiyah. Retrieved from www.okezone.com, 2007

[6] Hamayotsu, K. (Islam and nation building in Southeast Asia: Malaysia and Indonesia in comparative perspective. Pacific Affairs, Vol. 75, No. 3, pp. 353-375, 2002.

[7] Hermawan, R. S., \& Wisnubrata, A. Ahmadiyah diserang karena salah paham. Kompas. Retrieved from www.kompas.com, 2010

[8] Iskandar, Z. Gerakan Ahmadiyah Di Indonesia. Yogyakarta: LKiS, 2005.

[9] Liu, H., \& Asdhiana, I. M. Gubernur: Semoga jemaah Ahmadiyah insaf. Retrieved from www.kompas.com, 2011

[10] Riski, P. Jawa Timur larang aktivitas Ahmadiyah. Retrieved from www.voanews.com, 2011

[11] Joewono, B. N. Tersangka kasus cikeusik jadi 10 orang. Kompas. Retrieved from www.kompas.com, 2011

[12] Mahally, A. H. Benarkah Ahmadiyah Sesat? Catatan Bagi Umat Islam dalam Menyikapi Gerakan Ahmadiyah Internasional, Jakarta: PT Cahaya Kirana Rajasa, 2005.

[13] Sugandi. Upaya mengalihkan persoalan hukum. Bataviase, from www.bataviase.co.id, 2011

[14] Sundayani, R. Kekerasan terhadap Ahmadiyah meningkat. Inilah. Retrieved from www.inilah.com, 2011

[15] Waskita, F. Fuad Bawazier yakin insiden Ahmadiyah skenario pengalihan isu. Tribunnews, from www.tribunnews.com, 2011

[16] Widjaya, I. Lagi, puluhan rumah jamaah Ahmadiyah dirusak. Viva News. Retrieved from www.vivanews.com, 2010

[17] Yogaswara, A. Heboh Ahmadiyah: Mengapa Ahmadiyah Tidak Langsung Dibubarkan?, Yogyakarta: Penerbit Narasi, 2008 